\title{
GEOGRAPHY AND MATH TEACHERS IN DISTANCE LEARNING EDUCATION AMID COVID-19 PANDEMIC IN ALBANIA
}

Izvirni znanstveni članek COBISS 1.01

DOI: $10.4312 /$ dela.56.175-191

\section{Abstract}

The Coronavirus 2019 pandemic (COVID-19) brought a rapid change in the professional routine of in-service teachers worldwide. The study presents an assessment of challenges of online distance learning where a sample group of 155 geography and mathematics teachers, in pre-university system in Albania were involved during the first periods of the COVID-19 pandemic. The research found that lack of prior preparation has significantly affected the selection and usage of platforms, suitable for distance learning. Teachers face more difficulties in cartographic, graphic and symbolic semantic and less in verbal one. At the beginning of the pandemic, teaching was done mostly through WhatsApp and further on with the RTSH TV channels, followed by Google Classroom and Zoom. Teachers have fulfilled the needs for technological training through cooperation with colleagues and self-training and through various tutorials. The study emphasizes that teachers need professional development especially in software systems and online teaching methodologies.

Keywords: in-service geography and math teachers, distance teaching, COVID-19, ICT, teacher training

${ }^{\star}$ Department of Geography, Faculty of History and Philology, University of Tirana, Rr. E Elbasanit, 1000, Tiranë, Albania

${ }^{* *}$ Department of Information Technology, University College “Qiriazi”, Rr. Taulantët, Kodër-Kamëz,1029, Tiranë, Albania

${ }^{* * *}$ Department of Bussines Management, Logos University College, Rr Dritan Hoxha, in front of "Asllan Rusi" Sports Palace, 1000, Tiranë, Albania e-mail: jostina.dhimitri@unitir.edu.al, leka.pepkolaj@gmail.com,avdiablerta@gmail.com 


\section{UČITELJI GEOGRAFIJE IN MATEMATIKE V IZOBRAŽEVANJU NA DALJAVO V ČASU PANDEMIJE COVIDA-19 V ALBANIJI}

\section{Izvleček}

Pandemija COVID-19 je povzročila hitre spremembe v poklicni rutini učiteljev po vsem svetu. Raziskava, v katero je bila vključena vzorčna skupina 155 učiteljev geografije in matematike v Albaniji v začetnih obdobjih pandemije COVID-19, predstavlja oceno izzivov učenja na daljavo. Rezultati raziskave so pokazali, da je pomanjkanje predhodne priprave bistveno vplivalo na izbiro in uporabo spletnih platform, primernih za učenje na daljavo. Učitelji se srečujejo s težavami na področju kartografske, grafične in simbolne semantike, manj pa s težavami na področju verbalne semantike. $\mathrm{Na}$ začetku pandemije je poučevanje večinoma potekalo preko aplikacije WhatsApp, nadalje s televizijskimi kanali RTSH, sledilo je poučevanje v okoljih Google Classroom in Zoom. Učitelji so potrebe po tehnološkem usposabljanju spopolnjevali s sodelovanjem $s$ kolegi in samoizobraževanjem. V prispevku je poudarjeno, da učitelji potrebujejo strokovno spopolnjevanje, zlasti na področju programskih sistemov in metod spletnega poučevanja.

Ključne besede: učitelji geografije in matematike, poučevanje na daljavo, COVID-19, IKT, strokovno spopolnjevanje učiteljev

\section{INTRODUCTION}

On March 8, 2020, the first two cases of COVID-19 coronavirus were confirmed in Albania, and on the same day the government closed schools for two weeks. In addition, schools remained physically closed during this academic year and reopened only in September 2020, in 3 scenarios according to ASCAP (Pre-university Quality Assurance Agency), "Guidelines for the beginning of the academic year 2020-2021". This reopening depended on the Albanian regions, the evolution of the number of infected and deaths due to the pandemic. In June 2020, the schools opened only for the final year students in high school, in the pre-university system and for the final year students in the bachelor's and master's degree system at the university.

Pre-university education and teachers were in anything but a suitable state. Teaching and learning no longer had to be practised face-to-face, but digitally in online distance learning systems. Daniel (2020) states, "Most governments played catch-up to the exponential spread of COVID-19, so institutions had very little time to prepare for a remote-teaching regime." Although the use of ICT in teaching was embedded in 
some university curricula, most teachers were not accustomed to distance teaching and the lack of adequate infrastructure in schools had left both them and students unprepared. Several difficulties arose at the beginning of online teaching, which were firmly linked to the conversion of subjects to the online format and the lack of methods and pedagogical plans suitable for e-learning platforms. Teachers were confronted with certain situations, with little pedagogical or technical knowledge, that had to be implemented immediately. Often accompanied by stress, teachers had to adapt, increase collaboration among colleagues, and strictly follow the instructions given by local and central educational leaders. On the other hand, the MASR (Ministry of Education, Sports and Youth) provided maximum assistance in various instructions in schools, in accordance with the announcement of the Health Technical Committee. This Committee evaluated the progress of the pandemic and made recommendations for teaching. This was essential for the students and the pedagogical staff. There were no differences between primary and secondary schools.

\subsection{Literature review}

In distance learning, the figure of the teacher is still indispensable, even though his function changes in comparison with traditional teaching. $\mathrm{He} / \mathrm{she}$ changes from lecturer to facilitator of the teaching process, contributing to the preparation of the teaching material and supervising the interactive activities. Students should be encouraged to have more autonomy, participation, and responsibility for their learning process (Elliot, 2008; Trentin, 2014). Daniel (2020) says: "Teachers should work with what they know. Giving full attention to reassuring students is more important than trying to learn new pedagogy or technology on the fly". The WHO advised educators and students to use alternative learning due to the COVID -19 outbreak to mitigate the loss of instruction by providing a resource list from the World Bank's Edtech teams to provide some online materials that could be used during the pandemic.

The programme aimed to reduce learning loss and provide distance learning opportunities while schools were closed (Alea et al., 2020).

Currently, the forms of professional development for teachers according to Directive No. 1 of 20.01.2017 (MASR, 2017) are internal professional development, training, professional networks, counseling, long-term and short-term courses. Educational institutions that deal with the professional development of teaching staff aim, among other things, to provide teachers, especially those in service, with the necessary adaptability to maximize the fulfillment of needs and their adaptation to the task of developing the competencies of today's students.

A sustainable element of today's educational system is closely related to teacher training, both in terms of instrumental use of e-learning resources and various didactic-formative approaches related to their didactic continuity (Trentin, 2014). Since teachers nowadays, although they are constantly evolving, use traditional teaching 
methods (Chu et al., 2016), the need for modern professional development (Brysch, Boehm, 2014) arises with the use of technology in teaching and learning. Moreover, this professional development becomes an absolute priority (Chu et al., 2016), especially in the current learning situation under pandemic conditions.

The crucial role of traditional learning is by no means underestimated, even though we now have many successful e-learning methods (Brysch, Boehm, 2014; Dash et al., 2012) in various areas of mathematics and other sciences. Technology also helps in online professional development where space and time can be fully manipulated by us, according to one's own financial costs.

When it comes to integrating web technologies into didactic practice, one cannot ignore the gap that exists between students' personal and daily use of these technologies and the way teachers present them for research activities (Trentin, 2014). Moreover, teachers tend to present a use based on the methods and practices of "conventional" study and linked to the old teaching schemes, while instead it would be necessary to use new methodological presentations inspired by the so-called e-pedagogy (Elliot, 2008), able to fully exploit the potential of communication technologies both for social interaction and for access to knowledge.

Information technology is one of the key skills needed by today's teachers, as scholarly research and information organization are greatly supported by technology, e.g., in media creation and use (Boehm et al., 2012; Safar, Alkhezzi, 2013), digital storytelling (Chu et al., 2016), and especially e-learning platforms, where various software can be tightly integrated with their respective subjects. There is a growing trend of technology integration in the classroom that requires teachers to incorporate technology into their pedagogy. In particular, the Technological Pedagogical Content Knowledge (TPACK) model proposed by Mishra and Koehler (2006) is a frame of reference that helps teachers, including geography teachers (Trigueros, 2018), integrate technology into their teaching.

The positive side is that scientific research has given teachers the ability and confidence to teach using technology, but on the other hand, there are teachers who have difficulty implementing it in the classroom and even have little confidence in it (Chu et al., 2016; Kopcha, 2012). The technological infrastructure must be reliable and necessary to serve teachers' purposes. If using the technology is time consuming or does not contribute to the learning process, then this will discourage teachers from using it (Kopcha 2012). The availability of a technological infrastructure both at school and at home increases teachers' confidence in using ICT professionally (Chu et al., 2016). If teachers do not feel comfortable using technological tools or fear they are not skilled enough to learn how to use ICT, then they are less likely to incorporate technology into their teaching and even affect the little interaction students have with technology (Chu et al., 2016). However, the tools need to be carefully crafted: Content, methods for delivering content, and methods for teaching and learning, as well as methods for assessing student progress (Ohlin, 2019). 
There are difficulties in changing the way of teaching (Trentin, 2014): irregular use of the network in interaction with students; inability to enter into the logic of CMC (computer-mediated communication); lack of use of technologies. In general, teachers at all school levels indicated that their experience with online instruction was moderate to low (Lucisano et al., 2020). Teachers should provide high-quality professional development in flexible, effective formats that address their individual needs.

\section{METHODOLOGY}

The purpose of this study is to identify and analyze the challenges and needs of inservice teachers of geography and mathematics during the pandemic outbreak. Firstly a literature review on online learning was made and secondly a research with the participation of 155 geography and mathematics teachers working in several schools in Albania, both in rural and urban areas, was conducted. The applied aspect of the study is based on a survey. The analyzes were carried out in two dimensions: qualitative and quantitative. The questionnaire was distributed randomly based on the snowball technique. The instrument used for data collection is a Google Forms type questionnaire and consists of open and closed questions with predefined answers to allow qualitative analysis. The teachers who participated in this study were informed about the purpose of the study. In addition, ethical aspects were considered in the use of the questionnaires, ensuring that anonymity, confidentiality, and fair treatment of the participants were maintained. The questionnaire focused on: defining the difficulties encountered; the possibility of using online learning; the most common forms of communication with students before and at the beginning of the pandemic; the assessment of common needs as part of their professional development. Some questions used the Likert scale, which allowed the observation and analysis of frequencies of the variables, the analysis of cross-tabulations, especially between the variables and the teachers' work experience. Other analyzes focused on correlations and tests performed with the SPSS version 20 program. It is practical to apply the method of opinion analysis to collect important qualitative data (Albanese, 2020). Sentiment analysis was used to identify the platforms and applications most used by teachers.

\section{RESULTS AND DISCUSSIONS}

The survey was completed by 155 in-service teachers. A look at the demographic profile of the respondents shows that most of the respondents were female (117, i.e. $75.5 \%)$ and $38(24.5 \%)$ were male. $51 \%$ of the teachers worked in rural areas and $49 \%$ in urban areas. In the sample group, 145 (93.5\%) of the teachers worked in public schools and $10(6.5 \%)$ worked in private schools. Evaluating the highest diploma obtained by the survey participants and the professional categories, we find that teachers with university 
diplomas of 4 years of study (97 teachers) dominate, of which 73 (75.2\%) are subject teachers and highly qualified teachers. In-service teachers are graded based on their teaching experience. Each grade is reached by passing an examination, which can be taken after a certain length of professional experience. Teachers with less than 5 years of professional experience are classified as unclassified teachers; those with 5 to 10 years of professional experience are classified as qualified teachers; $10-20$ years of professional experience are qualified specialist teachers; and those with more than 20 belong to the category of highly qualified teachers. In short, a considerable number of teachers with considerable teaching experience participated in the study.

The second group of teachers includes those with bachelor's and MPM (Professional Master for Geography Teachers) degrees with 64 teachers, $67.45 \%$ of whom have less than 5 years of professional experience.

According to the professional years of teachers, the dominance of the specialist teachers can be seen (62 teachers, $40 \%$ ), followed by unclassified teachers (39 teachers, $25.2 \%$ ) of the whole sample. Highly qualified teachers account for $16.8 \%$.

Table 1: Crosstabulation between: "Which is your highest diploma" and "Which professional categories do you own".

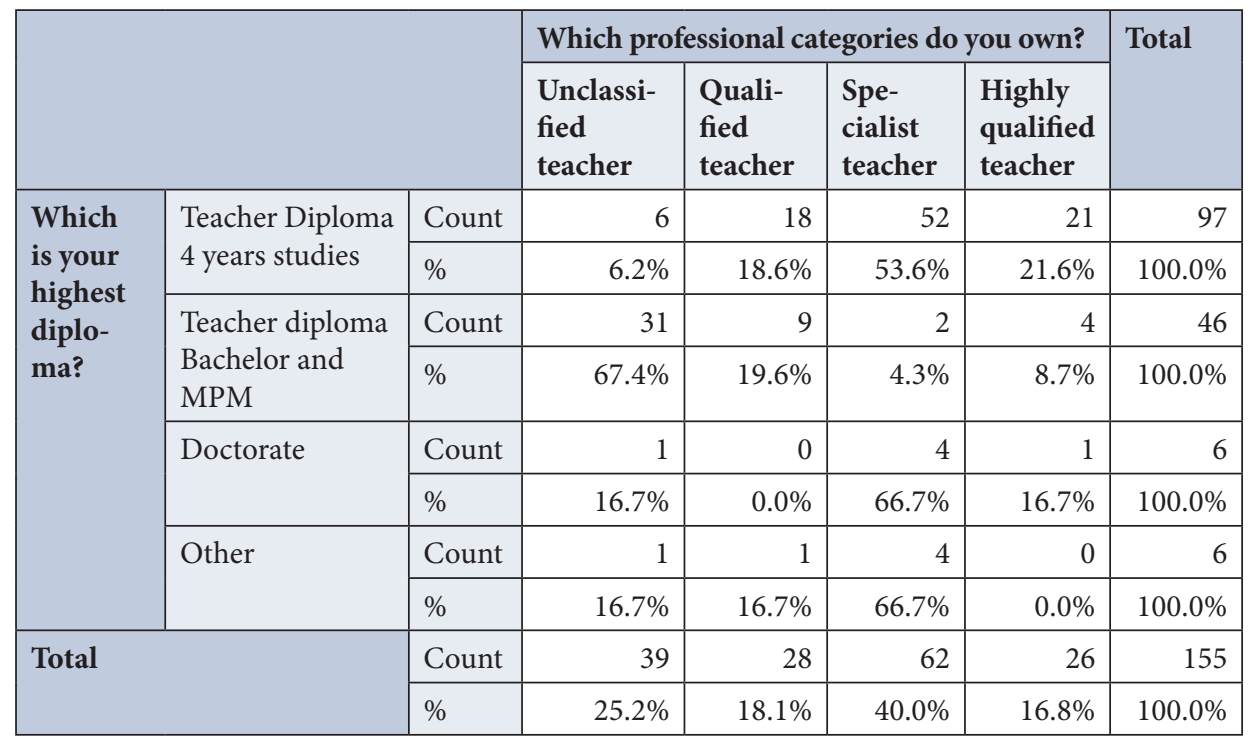

108 teachers (69.7\%) are teachers in the Geography profile and 47 teachers (30.3\%) are teachers in the Mathematics profile; 83 teachers (53.5\%) teach in the AMU (Low Middle Education) system, where the age of students is 11-15; 53 teachers (34.2\%) teach in the AML (High Middle Education) system, where the age of students is 1118 ; and 19 teachers teach in common schools where the age of students is 11-18. 
The results of the study show that most teachers did not engage in the development of distance education before the COVID-19 pandemic (65\%) and the rest used applications according to their specific needs (Figure 1).

Figure 1: Teachers and how they used online learning before the COVID-19 pandemic outbreak (number of responses).

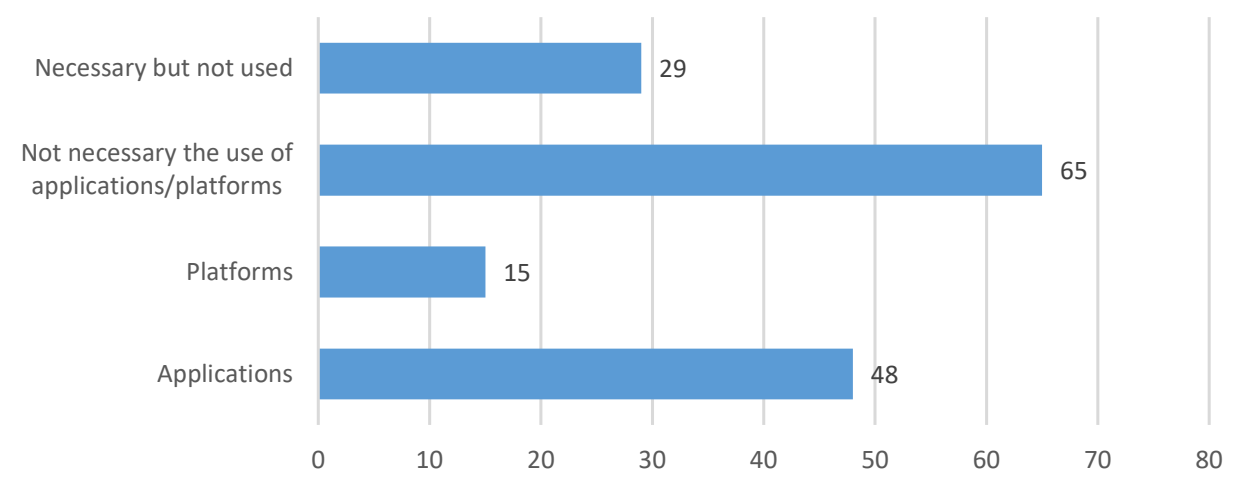

Teachers were asked to name 2 of the platforms or applications they used most frequently during the pandemic (Figure 2). Using the opinion mining analysis technique as software in semantic studies, a predominance of the words WhatsApp (155 times, i.e. $100 \%$ ), RTSH TV channels (84 times, 54.2\%), and Google Classroom, Google Meet (65 times, 41.9\%), Zoom (44 times, 28.4\%), etc. was found.

Figure 2: The platforms or applications most commonly used by teachers during the pandemic.

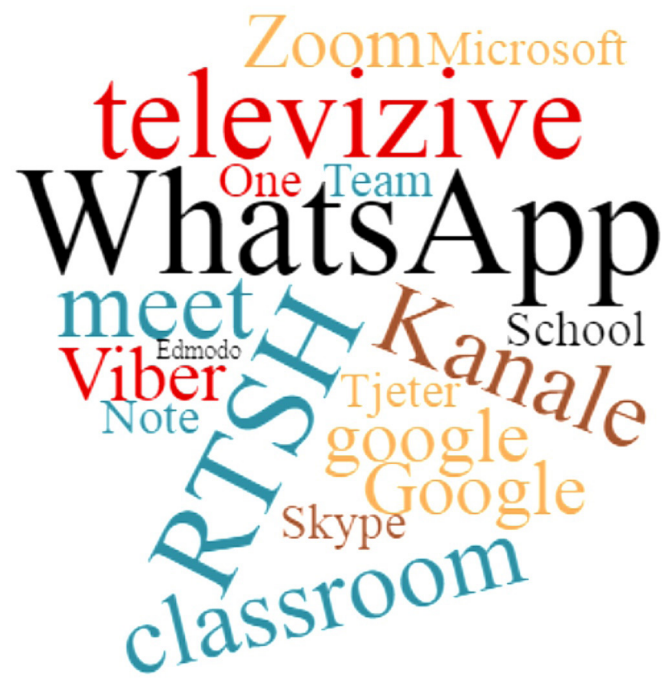


It was found that some of the solutions are part of UNESCO 2020's recommended solutions for distance education during the pandemic.

A paired sample t-test (Table 2) was estimated for two questions: A) How prepared do you feel for digital work in distance education? The variables were: 1) none, 2) a little, 3) not well, 4) well, 5) very well; and B) How was digital learning used before the pandemic? 1) Applications 2) Platforms 3) Use of applications and platforms was not required 4) Required but not used.

Null hypothesis $\left(\mathrm{H}_{0}\right)$ : there is no significant difference between the means of question $\mathrm{A}$ and $\mathrm{B}$. The difference in means is equal to 0 . The way how the teachers have performed digital learning before pandemic does not affect how prepared they feel to work in distance teaching.

Alternative Hypothesis (Ha): There is a significant difference between the means of questions $\mathrm{A}$ and $\mathrm{B}$, and the difference in the means is not equal to 0 . The way teachers have conducted digital learning before the pandemic has an impact on how prepared they feel for working in distance teaching.

Table 2: Paired sample t-test.

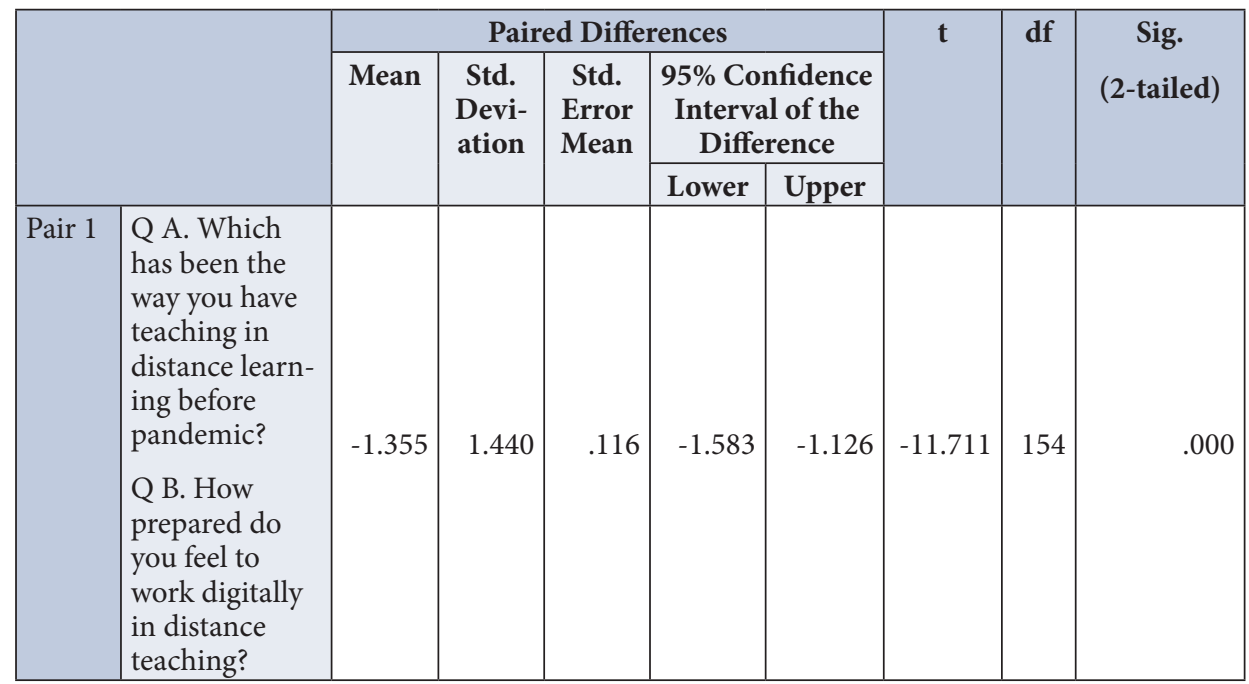

Interpretation of test results: Observed $t$-value $=-11.711$; Statistical significance (p-value $)=0.0005$. A p-value of $(0.0005)<0.05$ means that the null hypothesis is rejected and the alternative hypothesis is accepted. The test results show that there is a significant difference between the mean scores of questions A and B. The results indicate that how teachers used digital learning prior to the pandemic has an impact on how prepared they feel to work in distance teaching during the pandemic. 
One-sample t-test (Table 3). Question: how prepared do you feel for digital work in distance teaching? 1) none 2) a little 3) not well 4) well 5) very well. Pre-determined test score: $\mathrm{t}=4$. Null hypothesis $\left(\mathrm{H}_{0}\right)$ : population mean is significantly equal to 4 . Teachers feel well prepared to work digitally in distance teaching. Alternative hypothesis (Ha): The population mean is significantly different from 4 . Teachers do not feel well prepared to work digitally in distance learning.

Table 3: One-sample t-test.

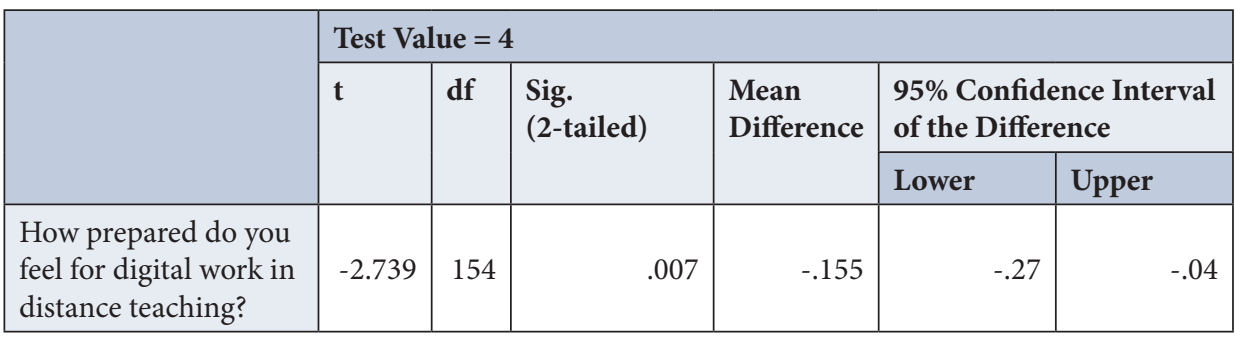

Interpretation of test results: T-criterion 1.64; observed $t$-value $=-2.739$. Statistical significance $(\mathrm{p}$-value $)=0.007$. A p-value of $(0.007)<0.05$ means that the null hypothesis is rejected and the alternative hypothesis is accepted. In summary, the test shows that the population mean is statistically significantly different from 4 . Specifically, the results show that teachers do not feel well prepared for digital work in distance teaching.

Teachers show a great interest in their professional development by considering training in technological teaching and, in particular, specialised technological training in $91.6 \%$ of the responses. The rest of the responses correspond to: I have no comment $5.8 \%$ and I disagree $2.6 \%$. Teachers are aware that technological training is necessary for their work, especially in the conditions of theCOVID-19 pandemic .

Teachers were asked how they should develop digital skills in their work at the beginning of the pandemic by selecting two options from the 5 offered: I do not develop, communication with colleagues, self-training through tutorials, participation in training provided by others (Figure 3). The answers showed that teachers prefer to develop their digital skills in their work mainly through self-training (118 of them), communication with colleagues (103 of them) and, in addition, through trainings offered by other trainers ( 75 of them). In Albania, self-directed learning served as a form of professional development for teachers. Lucisano et al. (2020) found in their study that collaboration with colleagues was considered effective - both for sharing teaching practices and for realizing interdisciplinary didactic pathways. Dhimitri et al. (2021), in their study conducted in 2020 and during a pandemic, estimated that self-directed learning enriches teachers with the competence to learn by gaining knowledge, attitudes, values for their professional and personal growth. They saw that teachers themselves were educated on issues of learning on platforms, online 
teaching, use of ICT software and hardware, Google classrooms, etc. In the didactic dimension, they preferred topics such as online teaching and learning techniques, assessment methods, ethical issues, competency-based learning, didactic use of the globe, maps, and so on. Meanwhile, Chang (2020) points out, "While online learning becomes prevalent, it also provides opportunities for teachers' professional development, such as the ability to observe each other's lessons through recorded video conferencing functionalities".

Figure 3: Teachers and development of digital skills in teachers' work in the first period of the COVID-19 pandemic (number of responses).

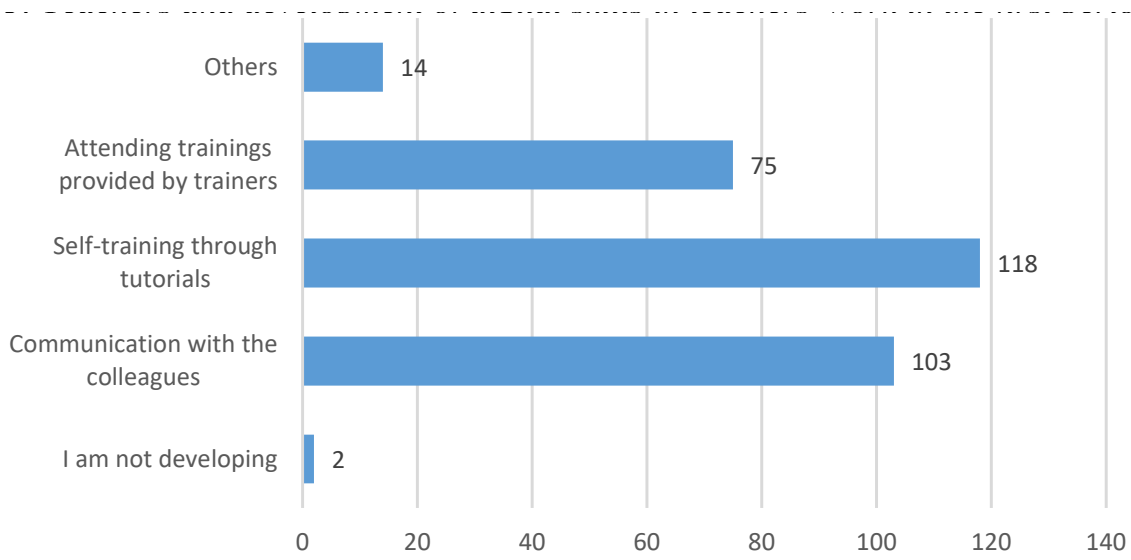

Teachers were asked about the support they need regarding distance education. Their answers showed that $51.6 \%$ of them asked for support in software applications (programmes), 37.4\% asked for support in online learning methods, and the rest asked for technical support (34.2\%)

In regard to the question "which semiotic systems have you encountered more difficulties with online services" teachers had to name two main difficulties for them. The answers showed that 95 (61.35\%) teachers had difficulties with cartographic uses, $86(55.5 \%)$ of them had difficulties with pictorial representations and 88 (56.8\%) teachers had difficulties with notes through symbols e.g. equation, meteorological symbols etc. 
Figure 4: Teachers and semiotic systems and the most frequently encountered difficulties in online services (number of responses).

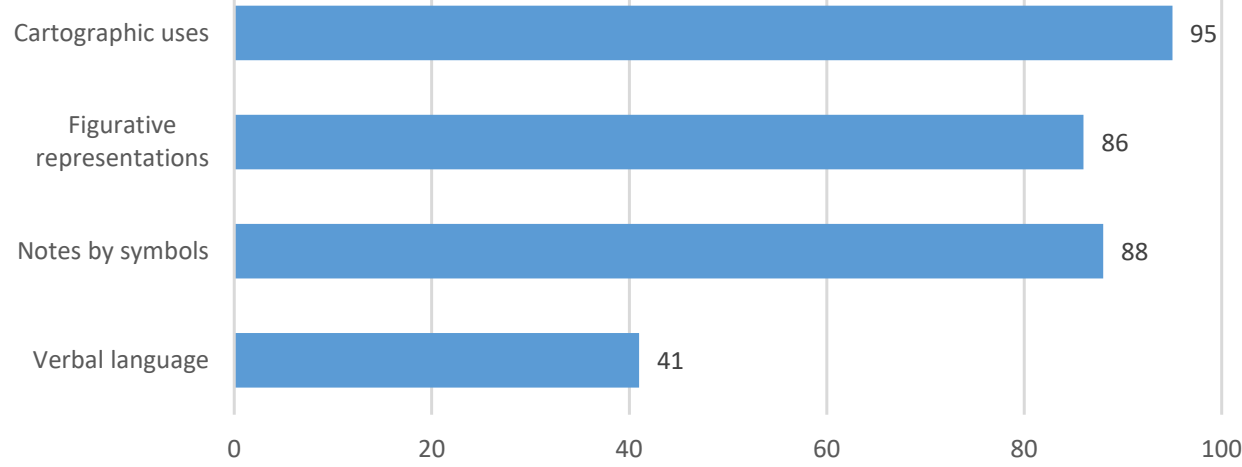

Table 4 is a correlation matrix that shows the correlation coefficients between different variables, the strength and the direction of this relationship. It shows that the correlations are statistically significant at $\mathrm{p}<0.01$. The correlations between variables are positive. They appear as moderate relationship (Salkind, 2000) especially in the cases where students interact with digital teaching lessons and learning and the estimation of the digital level of your school and moreover in digital work in distance education. A weak relationship exists between student interaction with digital lessons and learning and the platforms that allow teachers to decide and use the didactic activities. The most effective practice in response to teaching in an online environment is directed at students. Often students can become isolated in a virtual environment and feel helpless when challenged in a class. They need support and they need to feel that there is a human being present behind the computer screen (Schultz, DeMersb, 2022). 
Table 4: Pearson correlations among issues on remote teaching and learning in the COVID-19 pandemic.

\begin{tabular}{|c|c|c|c|c|c|}
\hline & & $\begin{array}{l}\text { How do you } \\
\text { estimate } \\
\text { the digital } \\
\text { level of your } \\
\text { school? }\end{array}$ & $\begin{array}{l}\text { How pre- } \\
\text { pared do you } \\
\text { feel to work } \\
\text { digitally } \\
\text { in distance } \\
\text { teaching? }\end{array}$ & $\begin{array}{l}\text { How does } \\
\text { the platform } \\
\text { allow you to } \\
\text { find and use } \\
\text { the didactic } \\
\text { activities? }\end{array}$ & $\begin{array}{l}\text { How do the } \\
\text { students } \\
\text { interact } \\
\text { with digital } \\
\text { lessons and } \\
\text { learning? }\end{array}$ \\
\hline \multirow{3}{*}{$\begin{array}{l}\text { How do you } \\
\text { estimate the } \\
\text { digital level of } \\
\text { your school? }\end{array}$} & $\begin{array}{l}\text { Pearson } \\
\text { Correlation }\end{array}$ & 1 & $.441^{* *}$ & $.522^{* *}$ & $.509^{* *}$ \\
\hline & $\begin{array}{l}\text { Sig. } \\
\text { (2-tailed) }\end{array}$ & & .000 & .000 & .000 \\
\hline & $\mathrm{N}$ & 155 & 155 & 155 & 155 \\
\hline \multirow{3}{*}{$\begin{array}{l}\text { How prepared } \\
\text { do you feel to } \\
\text { work digitally } \\
\text { in distance } \\
\text { teaching? }\end{array}$} & $\begin{array}{l}\text { Pearson } \\
\text { Correlation }\end{array}$ & $.441^{* *}$ & 1 & $.413^{* *}$ & $.430^{* *}$ \\
\hline & $\begin{array}{l}\text { Sig. } \\
\text { (2-tailed) }\end{array}$ & .000 & & .000 & .000 \\
\hline & $\mathrm{N}$ & 155 & 155 & 155 & 155 \\
\hline \multirow{3}{*}{$\begin{array}{l}\text { How does the } \\
\text { platform allow } \\
\text { you to find and } \\
\text { use the didactic } \\
\text { activities? }\end{array}$} & $\begin{array}{l}\text { Pearson } \\
\text { Correlation }\end{array}$ & $.522^{* *}$ & $.413^{* *}$ & 1 & $.399^{* *}$ \\
\hline & $\begin{array}{l}\text { Sig. } \\
\text { (2-tailed) }\end{array}$ & .000 & .000 & & .000 \\
\hline & $\mathrm{N}$ & 155 & 155 & 155 & 155 \\
\hline \multirow{3}{*}{$\begin{array}{l}\text { How do the } \\
\text { students } \\
\text { interact with } \\
\text { digital lessons } \\
\text { and learning? }\end{array}$} & $\begin{array}{l}\text { Pearson } \\
\text { Correlation }\end{array}$ & $.509^{* *}$ & $.430^{* *}$ & $.399^{* *}$ & 1 \\
\hline & $\begin{array}{l}\text { Sig. } \\
\text { (2-tailed) }\end{array}$ & .000 & .000 & .000 & \\
\hline & $\mathrm{N}$ & 155 & 155 & 155 & 155 \\
\hline
\end{tabular}

${ }^{*}$ *Correlation is significant at the 0.01 level (2-tailed).

\section{CONCLUSIONS}

The purpose of this study was to provide a general snapshot of geography and mathematics teachers' online learning experiences during the COVID-19 outbreak. Complications in coping with the pandemic also occurred in pre-university education. However, teachers never stopped working to ensure children's right to education, albeit under unusual circumstances and with immediate change. Decision makers turned their attention in this direction by directing, planning, and aligning educational institutions. Although the current curriculum was introduced in 2015, in which teachers' 
digital literacy is a key part, the study shows that most teachers did not fully possess this literacy when the pandemic broke out. The lack of digital literacy among teachers is also evident in the applications used during the pandemic. The use of applications that are not intended for didactic purposes is striking.

At this stage, the use of low synchronous learning is striking. The results of the paired samples t-test show that the nature of teaching during the pandemic is strongly dependent on pre-pandemic teacher preparation. The results of the one sample t-test show that teachers do not feel adequately prepared for distance learning. They tend to show a great need in their professional development in terms of technology training in teaching and especially in professional technology training.

However, the study showed that teachers could respond professionally. Although they were instructed or often autonomous, they were able to respond to their needs by self-training, interacting with colleagues, or through multiple tutorials. Interaction among teachers to respond to their professional needs became increasingly evident.

We can distinguish different software, platforms or applications suitable for distance learning, such as Mathematica, Geogebra, Google Earth, Mind Mapper, Google Workspace for Education, Excalidraw virtual whiteboard, ZoomTM, virtual tours to assist in field research, etc. However, virtual reality fieldwork will not be able to replicate the senses of touch and smell, which are important experiences of fieldwork (Chang, 2020).

Our teachers have not yet overcome the technocentric stage. Many theoretical models have been developed that aim to evaluate the readiness to use technology through the acceptance and use of technology in different areas of life. TAM (Technology Acceptance Model) is one of them. After several modifications, this model was proposed by Davis (1989), which evaluates perceived usefulness (PU) and perceived ease of use (PE) to predict teachers' attitudes toward technology use (Wang, 2021). The model assumes that when users are presented with a modern technology, a number of factors influence users' decisions about how and when they will use a modern technology (Silva, 2015).

Technology was an important component of professional practise during the COVID-19 pandemic. Under post-pandemic conditions and the school's return to pre-pandemic learning conditions for the 2021-2022 school year, but due to health limitations, the role of technology is no longer the same. It is no longer mandatory or necessary for teachers as it was for distance learning. However, we propose the use of a large-scale application TAM for teachers, administrators, etc. as individual adoption and use of innovative technologies in the work context. Teachers' desire and professional commitment to technology, based on the perceived usefulness and perceived ease of use of the TAM technology, would provide the technological foundation for the didactics of geography, mathematics, and other subjects. Although this model may be influenced by a number of personal factors, such as: socioeconomic, technical, etc., we propose that it be integrated into the professional aspects of the teacher's work. 
Professional networks are part of teachers' CPD. They can provide individuals, exclusively teachers, with a comprehensive awareness of how to use and integrate technology into the teaching process. Through this study, more ideas and opportunities of professional networks that need to address digital literacy are created. In addition, the study proposes professional development trainings and seminars on various pedagogical approaches and methods that are appropriate for online learning. By strengthening the foundations of technology as a tool for providing didactic solutions, we can create a desire for its professional use in schools.

Because the study was conducted during COVID-19, the available time and scope were limited. We propose to conduct future studies involving a larger group of teachers-in-training and teachers of other subjects at the country level.

\section{Acknowledgments}

This study was conducted at the initiative of the authors, experts in geography and mathematics education. It is not supported by any funding source. The authors would like to thank the teachers who participated in the survey.

\section{References}

Albanese, V., 2020. La sentiment analysis a supporto della ricerca geografica. Un esempio applicativo per il turismo salentino. URL: https://www.researchgate.net/publication/345179579_La_sentiment_analysis_a_supporto_della_ricerca_geografica_ Un_esempio_applicativo_per_il_turismo_salentino/stats (accessed 21.07.2021).

Alea, L., Fabrea, M., Roldan, R., Farooqi, A., 2020. Teachers' Covid-19 awareness, distance learning education experiences and perceptions towards institutional readiness and challenges. International Journal of Learning, Teaching and Educational Research. 19, 6, pp. 127-144. URL: 10.26803/ijlter.19.6.8.

ASCAP, 2020. URL: https://www.ascap.edu.al/wp-content/uploads/2020/09/Udhezuesi-per-fillimin-e-vitit-shkollor-2020-2021.pdf (accessed 25.07.2021).

Boehm, R. G., Brysch, C. P., Mohan, A., Backler, A., 2012. A new pathway: Video-based professional development in geography. Journal of Geography, 11, 2, pp. 41-53.

Brysch, C. P., Boehm, R. G., 2014. Online professional development in geography: the learning cluster method and teacher leader. European Journal of Geography, 5, 1, pp. 62-69.

Chang, Ch., 2020. Teaching and learning geography in pandemic and post-pandemic realities. J-READING, Journal of research and didactics in geography, 2, 9, pp. 31-39. URL: http://j-reading.org/index.php/geography/article/view/267/214 (accessed 02.01.2022).

Chu, S., Reynolds, R., Notari, M., Taveres, N., Lee, C., 2016. 21st century skills development through inquiry based learning from theory to practice. Springer Science. 
Daniel, S. J., 2020. Education and the COVID-19 pandemic. Prospects, 49, pp. 91-96. URL: DOI: 10.1007/ s11125-020-09464-3.

Dash, S., de Kramer, R. M., O’Dwyer, L. M., Masters, J., Russell, M., 2012. Impact of online professional development on teacher quality and student achievement in fifth grade mathematics. Journal of Research on Technology in Education, 45, 1, pp. 1-26.

Davis, F. D., 1989. Perceived usefulness, perceived ease of use, and user acceptance of information technology. MIS Quarterly, 13, 3, pp. 319-340. DOI: 10.2307/249008.

Dhimitri, J., Karaguni, M., Bardhoshi S., 2021. Self-directed learning dimensions and in-service geography teachers in Albania. Journal of Educational Research, 3, 5-6, pp. 30-38. URL: https://eprints.unite.edu.mk/848/1/EDUCATION\%202021-3038.pdf (accessed 02.01.2022).

Elliot, 2008. E-pedagogy: does e-learning require a new approach to teaching and learning? URL: http://www.scribd.com/doc/932164/E-Pedagogy (24.07.2021).

Kopcha, T. J., 2012. Teachers' perceptions of the barriers to technology integration and 20 practices with technology under situated professional development. Computers \& Education, 59, 4, pp. 1109-1121.

Lucisano, P., Girelli, C., Becilacqua A., Virdia, S., 2020. Didattica in emergenza durante la pandemia Covid-19. Uno sguardo all'esperienza locale e nazionale degli insegnanti. RicercAzione, Research and innovation in Education, 12, 2, pp. 23-46 DOI: 10.32076/RA12 208 .

MASR, 2017, Guideline No. 1, date 20.01.2017. URL: https://ascap.edu.al/Biblioteka/ Zhvilli mi\%20Profesional\%20i\%20M\%C3\%ABsuesit/Udhezimi\%20zhvillimi\%20 profesional\%20-\%20Janar\%202017.pdf (accessed 24.07.2021).

Mishra, P., Koehler, M. J., 2006. Technological pedagogical content knowledge: A new framework for teacher knowledge. Teachers College Record, 108, 6, pp. 1017-1054.

Ohlin, C., 2019. Information and communication technology in a global world: Teachers' perceptions of continuing professional development. Research in Social Sciences and Technology, 4, 2, pp. 41-57.

Safar, A. H., Alkhezzi, F. A., 2013. Beyond computer literacy: Technology integration and curriculum transformation. College Student Journal. 47, 4, pp. 614-626.

Salkind, J. N., 2000. Statistics for people who (think they) hate statistics. Sage publication.

Schultz, R., DeMersb, M., 2020. Transitioning from Emergency Remote Learning to Deep Online Learning Experiences in Geography Education. Journal of Geography, 119, 5, pp. 142-146. DOI: 10.1080/00221341.2020.1813791.

Silva, P., 2015. Davis' Technology Acceptance Model (TAM) (1989). URL: https://www. igi-global.com/viewtitlesample.aspx?id=127133\&ptid=120225\&t=Davis $\% 27 \% 20$ Technology\%20Acceptance\%20Model\%20(TAM)\%20(1989)\&isxn=978146668 (accessed 03.01.2022).

Trentin, G., 2014. Formazione degli insegnanti: tra formale, informale e digitale. In M.E. Cadeddu (a cura di) Il CNR e la Scuola. Roma: Edizioni CNR. 
Trigueros, I., 2018. New learning of geography with technology: the TPACK model. European Journal of Geography, 9, 1, pp. 38-48.

UNESCO, 2020. Distance learning solutions, URL: https:/en.unesco.org/covid19/ education response/solutions (accessed 30.07.2021).

Wang, Y., 2021. In-service teachers' perceptions of technology integration and practices in a Japanese university context, The JALT CALL Journal, 17, 1, pp. 45-71. DOI: 10.29 140/jaltcall.v17n1.377.

\section{UČITELJI GEOGRAFIJE IN MATEMATIKE V IZOBRAŽEVANJU NA DALJAVO V ČASU PANDEMIJE COVIDA-19 V ALBANIJI}

\section{Povzetek}

Albanija je 8. marca 2020 potrdila prva dva primera koronavirusa COVID-19, še isti dan pa je vlada zaprla šole za dva tedna. Šole so v tem šolskem letu ostale fizično zaprte, ponovno pa so jih odprli septembra 2020, in sicer po treh scenarijih v skladu z ASCAP 2020, „Smernicami za začetek šolskega leta 2020-2021«. Ponovno odprtje je bilo odvisno od števila okuženih in žrtev v različnih regijah Albanije. Preduniverzitetno izobraževanje in zlasti učitelji so se znašli v povsem neprimernih razmerah.

Poučevanje in učenje je bilo treba nemudoma prilagoditi digitalnemu načinu $\mathrm{v}$ spletnih sistemih učenja na daljavo. Že na začetku spletnega poučevanja in učenja so se pokazale številne težave. Predmeti so se izvajali v spletni obliki, pri tem pa niso bile uporabljene metodologije, primerne za platforme e-učenja. Učitelji so se pogosto soočali s stresom, saj so se morali sami usposabljati, povečati sodelovanje s sodelavci ter dosledno upoštevati navodila lokalnih in osrednjih vodij izobraževanja.

Didaktična raba informacijske tehnologije je ena od ključnih kompetenc današnjih učiteljev. Od učiteljev se vse bolj pričakuje, da tehnologijo vključijo v svoje poučevanje. Zlasti model tehnološko-pedagoškega vsebinskega znanja (TPACK), ki sta ga predlagala Mishra in Koehler (2006), je referenčni okvir za pomoč učiteljem (Isabel 2018) pri vključevanju tehnologije $\mathrm{v}$ pouk.

Namen raziskave je bil identificirati in analizirati izzive in potrebe učiteljev geografije in matematike v času nastopa pandemije. V njej je sodelovalo 155 učiteljev, zaposlenih na različnih šolah v Albaniji. Aplikativni vidik študije temelji na izvedeni anketi. Analize so bile opravljene v dveh metodoloških razsežnostih: kvalitativni in kvantitativni. Orodje, uporabljeno za zbiranje podatkov, je vprašalnik tipa Google for$m s$, ki je sestavljen iz vprašanj zaprtega in odprtega tipa, kar omogoča tudi kvalitativno analizo. Namen vprašalnika je bil: opredeliti težave, s katerimi se srečujejo učitelji; možnost uporabe spletnega učenja; najpogostejše oblike komunikacije $\mathrm{z}$ učenci pred 
začetkom pandemije in po njem; oceniti najpogostejše potrebe $\mathrm{v}$ okviru njihovega strokovnega razvoja. Pogled v demografski profil anketirancev kaže, da je bila med 155 udeleženci raziskave večina žensk, in sicer 117 (75,5 \%), 38 (24,5 \%) pa moških. $51 \%$ učiteljev je delalo na podeželju, $49 \%$ pa v mestih. 145 (93,5 \%) učiteljev je delalo v javnih, 10 (6,5 \%) pa v zasebnih šolah. 56,8 \% učiteljev je uvrščenih med učitelje specialiste in visokokvalificirane učitelje, saj imajo več kot 10 let delovnih izkušenj kot učitelji. 108 anketirancev (69,7 \%) je učiteljev geografije, 47 učiteljev (30,3 \%) pa je učiteljev matematike.

Večina učiteljev se pred pandemijo ni posvečala poučevanju na daljavo (65\%), ostali pa so uporabljali aplikacije glede na svoje specifične potrebe. Učitelji so bili naprošeni, da izpostavijo dve od platform ali aplikacij, ki so jih med pandemijo najbolj uporabljali. S tehniko analize "Opinion mining" kot programske opreme v semantičnih študijah je bila ugotovljena prevlada besed WhatsApp (155-krat), RTSH TV kanali (84-krat), Google Classroom in Google Meet (65-krat), Zoom (44-krat) itd.

Učitelji (91,6 \% odgovorov) kažejo veliko zanimanje za svoj strokovni razvoj v zvezi s tehnološkim usposabljanjem pri pouku in še posebej za predmetno tehnološko usposabljanje. Odgovori so pokazali, da učitelji pri svojem delu največkrat razvijajo digitalne spretnosti s pomočjo samoizobraževanja (118) in komunikacije med kolegi (103), pa tudi z usposabljanji, ki jih izvajajo drugi (75).

\section{(Prevod Arsim Ejupi)}

